\title{
Research on the Impact of Brand Experience on Brand Love
}

\author{
Xi Zhang \\ Department of Business Administration, Daejeon University, Daejeon, South Korea \\ Email: Zoezhang71@163.com
}

How to cite this paper: Zhang, X. (2019) Research on the Impact of Brand Experience on Brand Love. American Journal of Industrial and Business Management, 9, 898-903.

https://doi.org/10.4236/ajibm.2019.94061

Received: March 25, 2019

Accepted: April 15, 2019

Published: April 18, 2019

Copyright $\odot 2019$ by author(s) and Scientific Research Publishing Inc. This work is licensed under the Creative Commons Attribution International License (CC BY 4.0).

http://creativecommons.org/licenses/by/4.0/

\section{cc) (i) Open Access}

\begin{abstract}
Based on the systematic review of existing literature, this paper theoretically demonstrates the relationship between brand experience and brand love, and proposes corresponding hypotheses. Consumers with consumption experience of themed brands were selected as research samples. Hierarchical regression analysis was used to test the effects of sensory, emotional and social experience on brand love, as well as the moderating effect of self-fragmentation on the relationship between surreal experience and brand love. The results show that: The sensory experience, emotional experience and social experience in the surreal experience all have a significant positive impact on brand love. Self-fragmentation plays a positive role in regulating the relationship between social experience and brand love. Self-fragmentation has no significant moderating effect on the relationship between brand love and sensory experience and emotional experience.
\end{abstract}

\section{Keywords}

Brand Experience, Brand Love, Correlational Research

\section{Introduction}

At present, the influencing factors of brand love include brand identity, brand community, service quality, customer satisfaction, hedonic brand and self-expression brand. However, the existing research on the influence of consumption experience on brand love has some deficiencies in the aspects of influencing factors, forming reasons and how to cultivate brand love. In the field of commodity economy, consumers, especially young consumers, tend to be curious about new things. The purchase process and post-purchase evaluation are easily affected by external environment. They have positive feelings about the products and services they have bought. This emotion is extended through the 
interpersonal love emotion between people in psychology and applied to the consumption field, which is called brand love. In view of this, this study will explore the relationship between surreal experience and brand love, as well as the moderating effect of self-fragmentation on the relationship between them through empirical research methods, taking consumers with thematic brand consumption experience as the research object.

Although scholars at home and abroad have different understandings of brand experience, they all agree that brand experience requires interaction between customers and brands. This paper agrees with the definition of Schmitt, that is, brand experience is a behavioral response caused by sensation, perception and stimulus related to brand. This definition is concluded by combining the characteristics of brand experience based on Schmitt's understanding of experience, which is more consistent with the connotation of brand experience in this study.

The article is organized as follows: Literature Review, Proposal of Hypotheses, Research Design, Results and Discussion.

\section{Literature Review}

\subsection{Brand Experience}

Brand experience is the initial experience, which forms the sensory stimulation through vision, hearing, taste and touch, producing primary emotional responses such as joy, satisfaction or disappointment. Sensory experience is easier to realize and stimulate, which is the dimension of consumption experience that scholars agree with. Oliver's research shows that perceptual experience has a significant impact on consumer satisfaction behavior. During the experience of a product or service, consumers will experience positive or negative feelings or emotions such as satisfaction, novelty, disappointment, etc. Experience can be discussed from the perspectives of marketing, philosophy and aesthetics [1]. Brakus and other researchers divide the experiences into "product experience" during the process of contact with the product, "patronage and service experience" during the patronage and receiving service process and "shopping experience" during product use process [2]. Customer experience is the consumer's cognition, emotion, mood, social and material reaction to products and brands.

\subsection{Brand Love}

The research of brand love started late at home and abroad. Carroll \& Ahuvia defined and measured brand love for the first time. They proposed that brand love was the emotional dependence on the brand of highly satisfied consumers, which includes positive emotional response, positive brand evaluation, brand attachment and declaration of brand love [3] [4]. Different fields have different interpretations of love. The conceptual framework of love is also different. The extended brand love is a new concept in marketing, which is mainly used to evaluate the emotional attachment of satisfied consumers to a specific brand. 
Through literature review, this study believes that brand love refers to the emotional separation of love from interpersonal relationships, with passion and intimacy as the main emotional colors, showing emotional dynamics such as fanaticism, attachment and worship, and involving positive cognitive and emotional attributes. The premise of brand love is to pay attention to the emotional experience of consumers. So it is based on the study of the interaction between consumers and brand experience perspective, emphasizing the positive feelings of consumers towards the brand. We emphasize how young consumers consider the psychology of love objects, specifically, the positive feelings of satisfied consumers towards brands.

\section{Proposal of Hypotheses}

Sensory experience enables individuals to have a unique "emotional capability" of their favorite products, that is, they can obtain a sense of pleasure and satisfaction, and thereby construct the meaning of themselves, which also means that consumer atmosphere will promote individuals to actively experience the environment or products with strong sensory colors, and deepen their impression and favorable impression of the brand through unique feelings [5] [6]. Thus, sensory experience positively affects brand emotion, brand intimacy and brand passion. Therefore, the following hypotheses are proposed:

Hypothesis 1: Sensory experience positively affects consumers' brand love.

Pleasant consumption experience will promote consumers to have positive, active and effective cognition, use and communication of products or services. They are willing to pay for the brand, such as buying at a premium, which will stimulate consumers' desire and attachment to the brand. Therefore, the following hypotheses are proposed:

Hypothesis 2: Emotional experience positively affects consumers' brand love.

Social experience is the highest stage of experience. Through dreaming and unexpected consumption experience, consumers can enjoy the unique and surreal environment to the fullest, improve their cognition and evaluation of the brand, and promote the generation of their beloved emotion. Therefore, the following hypotheses are proposed:

Hypothesis 3: Social experience positively affects consumers' brand love.

\section{Research Design}

\section{1) Sample Data Collection}

This research mainly carries on the questionnaire survey to the consumer who has had the subject brand experience. There are two main types of respondents: One type includes the theme brand dining customers, whose consumption service receiving, experience evaluation is more real and accurate in the theme brand. The other type includes the customers who have visited the theme brand for many times. They have emotional dependence on the theme brand and have a more comprehensive evaluation of the previous experience. A total of 500 
questionnaires were distributed in this survey, and 451 questionnaires were recovered, among which 426 were valid and the recovery rate was $85.2 \%$. Among the questionnaires, 98 questionnaires were distributed through network channels, and 58 were effectively recovered.

\section{2) Variable Design and Measurement}

The research design of the five variables in this research was supported by relevant theories or literature, and the mature scale was used for reference [3] [4]. After many modifications and tests, a preliminary questionnaire was formed.

\section{Empirical Results}

\subsection{The Survey Questionnaire Is Shown in Table 1}

Table 1. Survey questionnaire.

\begin{tabular}{|c|c|}
\hline & Survey Questions \\
\hline \multirow{5}{*}{ Brand Experience } & $\begin{array}{l}\text { The consumption in this brand makes me feel like I belong to a certain consumer } \\
\text { group. }\end{array}$ \\
\hline & $\begin{array}{l}\text { The consumption in this brand makes me feel that I have the same consumption } \\
\text { concept with other consumers. }\end{array}$ \\
\hline & The consumption in the brand has strengthened my relationships with others. \\
\hline & The brand allows me to experience a different life experience. \\
\hline & $\begin{array}{l}\text { I like to talk about this theme brand with other consumers who have } \\
\text { consumption in this brand. }\end{array}$ \\
\hline \multirow{8}{*}{ Brand Love } & The theme brand allows me to engage in special role-playing. \\
\hline & The theme brand makes me feel good. \\
\hline & The brand lets me yearn. \\
\hline & The brand makes me passionate. \\
\hline & The relationship between me and the brand's theme brand is intimate. \\
\hline & I would like to experience this type of brand. \\
\hline & The theme brand has deeply attracted me. \\
\hline & When choosing similar products, this brand is my first choice. \\
\hline
\end{tabular}

\subsection{Correlation Coefficients between Six Variables}

Between 0.3 and 0.5 , the common variation value between variables is not high, as shown in Table 2. The data show that the research hypothesis and relationship model are reasonable, so the relationship between variables can be further analyzed.

It can be seen from Table 3 that sensory experience, emotional experience and social experience have a significant positive impact on brand love at the level of significance 0.001 . Hypothesis 1, hypothesis 2 and hypothesis 3 are verified from the analysis.

When investigating what aspects of a brand attract consumers, it is found that staff enthusiasm, business hall decoration and staff wear account for a similar proportion. 
Table 2. Correlation coefficient matrix.

\begin{tabular}{|c|c|c|c|c|c|}
\hline Variable & 1 & 2 & 3 & 4 & 5 \\
\hline Sensory Experience & 0.752 & & & & \\
\hline Emotional Experience & $0.725^{\star *}$ & 0.754 & & & \\
\hline Social Experience & $0.712^{* *}$ & $0.763^{\star *}$ & 0.717 & & \\
\hline Brand Love & $0.672^{* *}$ & $0.652^{* *}$ & $0.699^{* *}$ & $0.380^{* *}$ & 0.727 \\
\hline
\end{tabular}

Note: ${ }^{* *}$ indicates significant level $\mathrm{P}<0.01$ (double-tailed test).

Table 3. Regression analysis of independent variables to outcome variables.

\begin{tabular}{ccccc}
\hline & & Sensory Experience & Emotional Experience & Social Experience \\
\hline \multirow{2}{*}{ Brand Love } & sig. & $0.298^{* * *}$ & $0.146^{*}$ & $0.354^{* * *}$ \\
& t value & 5.248 & 0.02 & 0 \\
\hline
\end{tabular}

Note: ${ }^{* *}$ indicates $\mathrm{P}<0.001$, ${ }^{*}$ indicates $\mathrm{P}<0.05$ (2-tailed); $R^{2}$ is 0.585 , standard deviation is 0.653 , the value of $\mathrm{F}$ is 49.159 .

According to the research data, $89 \%$ of the students are more likely to contact people who use a certain brand, which shows that college students prefer to join a certain group, hoping that they can have a sense of belonging and can communicate with people who have similar hobbies. For a brand, its most basic business is to contact others.

\section{Discussion \& Conclusion}

According to previous studies by scholars, consumers strengthen their social relationship with others through brand consumption, and they will have a kind of love and attachment to the brand itself. However, this is not supported by data in this article. According to the respondents' evaluation of social relations in this paper, the average value is only 2.767, which is less than the median of 3.00 . Respondents rated the social relationship they obtained from brand consumption as low, or they did not feel the strengthening of social relationship construction at all. This may be related to the group of interviewees and the brand of the survey [4].

Sensory experience and emotional experience both have a significant positive impact on brand love, which indicates that postmodern consumers, especially young college students, pay more attention to the detail design in the theme brand environment. Therefore, in the environmental design and site facilities construction, sound, light, electrical design, picture decoration and other resources should be made full use to achieve the appearance of landscape architecture. In terms of internal consumption environment, space design, interior furnishing, lighting design and other aspects are fully combined with the brand theme. It is necessary to improve service etiquette to meet consumers' requirements for sensory and emotional experience, and create an atmosphere that 
makes people relax in time. Both rest and entertainment can make people feel comfortable and happy, thus stimulating the formation of brand emotion such as yearning and pursuit.

Social experience has a significant positive impact on brand love. The cultural atmosphere of the theme brand is its selling point [4] [5] [6]. The expectation and demand of the target consumer group should be integrated into the theme culture to maintain the richness of the type and content of brand activities. The theme activity process should strengthen the participation of customers, not only to let customers participate in the activity as the audience, but also to encourage customers to participate in it as actors. Finally, the interaction between customers and customers is formed. The customers can enjoy the satisfaction of internal needs and identity expectations, experience the life experience of different cultures and the fun of role playing, and form the cultural resonance of subject and object.

The research conclusion mainly includes three points: First, there is an important connection between brand experience and brand love. Extraordinary customer experience is an important condition for the generation of brand love. Brand experience is an important variable, which has an important impact on the construction of consumers' social relations, personal and social self-presentation, as well as the entertainment enjoyment of consumers. Extraordinary experience encourages consumers to form brand love. Second, both personal and social self-identity have positive effects on brand love, and entertainment also plays an important role in brand love. Third, the influence of social relationship construction on brand love is not significant.

\section{Conflicts of Interest}

The author declares no conflicts of interest regarding the publication of this paper.

\section{References}

[1] Oliver, Rl., Rust, Rt. and Varki, S. (1997) Customer Delight: Foundation, Finding, and Managerial Insight. Journal of Reading, 73, 311-336. https://doi.org/10.1016/S0022-4359(97)90021-X

[2] Brakus, J.J., Schmitt, B.H. and Zarantonello, L. (2009) Brand Experience: What Is It? How Is It Measured? Does It Affect Loyahy? Journal of Marketing, 73, 52-68. https://doi.org/10.1509/jmkg.73.3.052

[3] Carroll, B.A. and Ahuvia, A.C. (2006) Some Antecedents and Outcomes of Brand Love. Marketing Letters, 17, 79-89. https://doi.org/10.1007/s11002-006-4219-2

[4] Wang, C.Z. and Zhou, X.C. (2012) Does Postmodernism Lead to "Infidelity"? How Does Surrealism and Self-Fragmentation Affect Consumers' Loyalty to Symbolic Brands. Journal of Marketing Science, 8, 11-29.

[5] Yang, D.F., Yang, J.H. and Wei, H.Y. (2010) Brand Experience, Self-Presentation and Brand Love. Journal of Business Economics, No. 10, 69-76.

[6] Zhang, L.R., Guan, Y.J. and Wang, Y. (2007) Brand Love: Conception and Development. Advances in Psychological Science, 15, 846-851. 